\title{
The Effect of Different Concentrations of Energia-M Growth Regulator on the Growth and Development of Solánum tuberósum L. plants
}

\author{
Anastasia Verizhnikova ${ }^{1, *}$, Svetlana Konoshina ${ }^{1}$, and Elena Prudnikova ${ }^{1}$ \\ ${ }^{1}$ Orel State Agrarian University named after N. V. Parakhin, 69, Generala Rodina St., Orel, 302019, Russian Federation
}

\begin{abstract}
The analysis of the available bibliographic data on the influence of silicon and its compounds on physiological processes in plants was carried out. The purpose of the work was to determine the effect of the organosilicon growth regulator Energia-M in concentrations of $10,50,80 \mathrm{mg} / \mathrm{l}$ on the growth and productivity of the early-ripening potato of the Zhukovsky cultivar grown on grey forest soils in a greenhouse. Low concentrations of Energia-M of 10,50 mg/l did not influence the growth and growth activity significantly. Energia-M in a concentration of $80 \mathrm{mg} / \mathrm{l}$ increased the growth activity of the potato plants considerably. One of the objectives of the research was to study the antioxidant properties of the growth regulator Energia-M for Solánum tuberósum plants. Treatment of Solánum tuberósum with low concentrations of the organosilicon growth regulator Energia-M had little effect on the catalase activity in leaves and tubers, peroxidase activity decreased. When treating the Solánum tuberósum plants with a high concentration of the growth regulator Energy-M, $80 \mathrm{mg} / \mathrm{l}$, the activity of catalase and peroxidase increased by 1.21 times. This pattern indicates the stimulation of metabolic processes in Solánum tuberósum plants grown on the grey forest soils of the Orel region with the application of the Energia-M growth regulator.
\end{abstract}

\section{Introduction}

Currently, the topical trend in the crop production development is the reduction of pesticide load in agrocenoses. The agroecological aspect of the application of silicon compounds in plant protection is particularly noteworthy. The role of silicon in the vital activity of plants has not been definitively clarified yet [1]. However, it is already known that this element is found in plant tissues partly in the form of organic compounds - silicon esters of carbohydrates, proteins and nucleic acids, and partly in the form of mineral compounds - silicic acids and silicates. Plants use moisture more productively when applying active forms of Si. About $30 \%$ of silicon contained in a plant takes part in maintaining the internal water supply, which plays an important role for plants in conditions of acute water shortage [2]. An important point of increasing xerophytism is the ability of silicon to reduce transpiration, as well as to change the angle of inclination of plant leaves, which subsequently reduces the level of moisture evaporation and increases the possibilities of plant antioxidant protection [3]. It has been proved experimentally that the absence of silicon affects the development of plants negatively: their growth slows down, earing is delayed, leaf necrosis appears, yield decreases, etc. [4]. On the contrary, addition of silicon compounds to the soil or to a water culture stimulates the formation of protective enzymes, polyphenol oxidase, peroxidase, catalase, which leads to an increase in the number of flavonoid compounds and phytoalexins with an antifungal effect [5].

In addition to increasing xerophytism, the plants under study showed an increase in fruit size, a decrease in acidity and an increase in the dry matter content in the fruit. The addition of silicates stimulates the photosynthetic activity of plants, earing and ripening of crops.

Nowadays, the use of plant growth regulators is one of the new agronomic technologies in crop production. In low doses they are able to influence metabolic processes in plants, which leads to significant changes in plants development [6]. In modern technologies, the great practical importance of growth regulators is determined by many conditions: influencing the processes of plant growth and development they are able to accelerate the growth or increase the yield of most agricultural crops significantly.

Violation of the technology of agricultural production has led to the accumulation of heavy metals in the fertile layer, as well as forms of macro - and microelements unavailable to plants [7].

That is why the use of environmentally friendly micro-fertilizers and growth regulators which allow using energy-saving technologies and maximizing the physiological capabilities of plants, allowing controlling the growth and development of agricultural crops, increasing their customer appeal, has become especially

\footnotetext{
* Corresponding author: anast94kor@mail.ru
} 
important in the development of vegetable growing $[8,9]$.

Among a huge variety of plant protection agents, growth regulators to which a synthetic plant growth regulator Energia -M belongs to play a special part. It is an organosilicon plant growth regulator based on active silicon.

Based on the above, the purpose of the work was defined: determination of specific features of the influence of the organosilicon growth regulator Energia$M$ based on the triethanolammonium salts of orthokresoxyacetic acid and 1-chloromethylsilatrane in various concentrations of the active material on the green matter and biochemical parameters of Solánum tuberósum plants of the Zhukovsky cultivar grown on the dark grey forest soils of the Orel region.

\section{Materials and methods}

Among a large number of agricultural crops, Solánum tuberósum is an eco-flexible crop, although in dry years, as well as in case of other extreme conditions, its yield decreases significantly.

The tubers of the Solánum tuberósum plant of the early-ripening Zhukovsky cultivar of domestic selection of 1993 were taken as the object of the study, as the most commonly used for cultivation in many regions of the Russian Federation, including the Central Chernozem region, to which the Orel region belongs to.

The soil used for the vegetation trial is a typical for the region dark grey middle loamy forest soil, it has the following agrochemical characteristics: humus content $3.59 \%$, pH-5.5; P2O5 content-28.85 mg/100 g of soil, exchangeable potassium (K2O) - $19.66 \mathrm{mg} / 100 \mathrm{~g}$ of soil; the content of easily hydrolysable nitrogen-14.00 $\mathrm{mg} / 100 \mathrm{~g}$ of soil; total nitrogen content-204.4 mg/100 g of soil.

Solánum tuberósum was treated with organosilicon growth regulator Energia-M by means of pre-planting soaking of tubers in an aqueous solution of the regulator in concentrations of $10 \mathrm{mg} / 1,50 \mathrm{mg} / 1,80 \mathrm{mg} / 1$ for 2 hours.

The trial was carried out under vegetational conditions (soil culture) in a soil culture using grey forest soil [10].

During the trial establishment, the optimal amounts of nitrogen, phosphorus and potassium $\left(\mathrm{N}_{90} \mathrm{P}_{60} \mathrm{~K}_{150}\right)$ for potatoes were added into the soil, respectively $2.3 \mathrm{~g}, 0.7$ $\mathrm{g}, 3.1 \mathrm{~g}$ of the element per pot. In a vegetative pot with $10 \mathrm{~kg}$ of soil, 1 plant was grown and a humidity of $60 \%$ of the total moisture capacity of the soil was maintained. The replication of the trial was fourfold.

The growth was determined by the linear method, the catalase activity was determined by the amount of oxygen released with further recalculation in terms of hydrogen peroxide. Peroxidase activity was determined by the Boyarkin method [11], benzidine was used as a substrate which forms a blue compound during oxidation. The activity of the enzyme was expressed in units per $1 \mathrm{~g}$ of wet weight. The veracity of the results was evaluated according to the Student's $t$-test.

\section{Results and discussion}

The analysis of the greenhouse trial was carried out upon the following indicators: shoot growth, shoot growth activity, catalase and peroxidase content.

At the stage of trial establishment, the weight of the vegetation pot with drainage was $25 \mathrm{~kg}, 10 \mathrm{~kg}$ of which was wet soil. The constant weight of the pot was maintained by watering by weight as the plant developed every 1-2 days. On days with ambient temperature above the average value for the specified period, the plants were weighed and watered in the morning and evening, which contributed to maintaining the optimal specified soil moisture.

Plant growth is an integral indicator of the course and direction of physiological processes. To determine the growth indicators on trial soil crops, the Solánum tuberósum plants were numbered and one of the stems was marked with a marker. In this plant, the marked stem was measured from the soil to the apical meristem daily. The measurement data was entered into the table.

The measurements were carried out from the moment of the emergence of mass sprouts until the beginning of flowering, when growth stops. According to the obtained data, the daily growth and growth activity are calculated using the following formula:

Ract. $=(\mathrm{h} 2-\mathrm{h} 1) / \mathrm{h} 1 * \mathrm{t} * 100 \%$,

where $\mathrm{h} l$ is the previous height, $\mathrm{mm}$;

$\mathrm{h} 2$ is the succeeding height;

$\mathrm{t}$ is the time, days;

Daily growth is calculated according to the formula $\Delta \mathrm{h}=(\mathrm{h} 2-\mathrm{h} 1) \mathrm{t}$,

where $\Delta \mathrm{h}$ ia the daily growth;

$\mathrm{h} 2$ is the succeeding height;

$\mathrm{h} 1$ is the previous height;

$\mathrm{t}$ is the time, days

Based on the obtained data, the stimulating effect of the synthetic growth regulator on potato plants was revealed. At the initial stage of the study, the high concentration of the growth regulator did not have a significant effect, the linear dimensions of the shoots of Solánum tuberósum plants were similar to the control plants. While the Energy-M variants $(10 \mathrm{mg} / \mathrm{L}, 50 \mathrm{mg} / \mathrm{L})$ compared to the control plants had more linear indicators (23\% and $14 \%$, respectively).

Over time, the effect of the studied growth regulator Energia-M in a concentration of $80 \mathrm{mg} / \mathrm{l}$ had a stimulating effect compared to the control variant and other concentrations of the growth regulator. The increase in the linear size of Solánum tuberósum plants in comparison with the control plants was $23.3 \%$ and $48.6 \%$, respectively, in the variants with the minimum and maximum concentrations of the applied agent. Energy-M in a concentration of $50 \mathrm{mg} / \mathrm{l}$ had an inhibitory effect on Solánum tuberósum plants and the linear parameters were $17.4 \%$ less than those in the control variant. (Table 1) 
Table 1. Influence of different concentrations of the organosilicon growth regulator Energia-M on the linear sizes of shoots of Solánum tuberósum

\begin{tabular}{|c|c|c|c|}
\hline Variant & Day 5 & Day 10 & Day 20 \\
\hline Control & 7.3 & 18.3 & 39.1 \\
\hline Energia-M, $10 \mathrm{mg} / 1$ & 9 & 22.5 & 48.2 \\
\hline Energia-M, $50 \mathrm{mg} / 1$ & 8.3 & 16.6 & 32.3 \\
\hline Energia-M, $80 \mathrm{mg} / 1$ & 7.3 & 25.6 & 58.1 \\
\hline
\end{tabular}

Treatment with low concentrations $(10 \mathrm{mg} / \mathrm{l}$ and 50 $\mathrm{mg} / \mathrm{l})$ of the organosilicon growth regulator Energia-M did not have a significant effect on the growth activity of shoots. While the concentration of the growth regulator Energia-M $80 \mathrm{mg} / \mathrm{l}$ increased the growth activity by 1.7 times (Table.2) compared to the control.

The value of the shoot growth indicators per day obeyed the same pattern and had the maximum length of shoots in the variant with a concentration of $80 \mathrm{mg} / \mathrm{l}$ (Table 2). The minimum growth of shoots was revealed when the Energy M-50 mg/l variant was applied, the daily growth of plants when Energy M-10 mg/l variant was used had an intermediate value.

Table 2. Influence of different concentrations of the organosilicon growth regulator Energia-M on the growth activity of potato plant shoots

\begin{tabular}{|c|c|c|}
\hline Variant & $\Delta \mathrm{h}, \mathrm{cm}$ & $\mathrm{R}$ act., $\%$ \\
\hline Control & $2.10 \pm 0.11$ & $30 \pm 2.00$ \\
\hline Energia-M-10 mg/1 & $2.80 \pm 0.14$ & $30 \pm 2.00$ \\
\hline Energia-M- $50 \mathrm{mg} / 1$ & $1.80 \pm 0.09$ & $20 \pm 1.00$ \\
\hline Energia-M-80 mg/1 & $3.80 \pm 0.19$ & $50 \pm 3.00$ \\
\hline
\end{tabular}

High concentrations of Energy-M at the first stages had a retarding effect on the height of shoots, which is probably due to the intensive formation of the green matter.

It is known that the antioxidant enzymes, catalase and peroxidase, play an important role in the formation of the protective properties of plants. Catalase is an enzyme of the oxidoreductase class that catalyzes the decomposition of hydrogen peroxide into water and molecular oxygen without the participation of oxygen acceptors, protecting the cells of living organisms from the oxidative action of peroxide. The role of the electron donor is performed by hydrogen peroxide. Peroxidase also reduces hydrogen peroxide to water, but uses organic compounds of the class of phenols, amines, and organic acids as hydrogen donors [12].

Peroxidase takes part in the biosynthesis of plant hormones such as ethylene, the regulation of auxin level, which is important for protecting plant tissues from damage by pathogenic microorganisms.

Both peroxidase and catalase influence the final amount of hydrogen peroxide in Solánum tuberósum.

As a result of the conducted studies, it was found out that the treatment of Solánum tuberósum plants with low concentrations of the organosilicon growth regulator Energia-M $(10 \mathrm{mg} / \mathrm{l})$ had little effect on the catalase activity in the leaves: $1370 \mu \mathrm{m} \mathrm{H} 2 \mathrm{O} 2 / \mathrm{g}$ of wet weight $/ \mathrm{min}$. Whereas the concentration of $50 \mathrm{mg} / 1 \mathrm{did}$ not have a stimulating effect and the activity of the enzyme was $1290 \mu \mathrm{m} \mathrm{H} 2 \mathrm{O} 2 / \mathrm{g}$ of wet weight/min. (Table $3)$.

Table 3. The effect of different concentrations of the growth regulator Energia-M on the activity of catalase in the organs of potato plants

\begin{tabular}{|c|c|c|}
\hline \multirow{2}{*}{ Variant } & \multicolumn{2}{|c|}{ Catalase activity, } \\
\cline { 2 - 3 } & \multicolumn{1}{|c|}{$\mathrm{H}_{2} \mathrm{O}_{2} / \mathrm{g}$ of wet weight $/ \mathrm{min}$} \\
\hline Control & $1339 \pm 67$ & Tuber \\
\hline $\begin{array}{c}\text { Energia-M, } \\
10 \mathrm{mg} / \mathrm{l}\end{array}$ & $1370 \pm 69$ & $419 \pm 21$ \\
\hline $\begin{array}{c}\text { Energia-M, } \\
50 \mathrm{mg} / \mathrm{l}\end{array}$ & $1290 \pm 65$ & $384 \pm 22$ \\
\hline $\begin{array}{c}\text { Energia-M, } \\
80 \mathrm{mg} / \mathrm{l}\end{array}$ & $1580 \pm 79$ & $500 \pm 25$ \\
\hline
\end{tabular}

A significant stimulating effect was observed when treating Solánum tuberósum plants with a high concentration $(80 \mathrm{mg} / \mathrm{L})$ of the organosilicon growth regulator Energia-M. The catalase activity in this case was $1580 \mu \mathrm{m} \mathrm{H} 2 \mathrm{O} 2 / \mathrm{g}$ of wet weight $/ \mathrm{min}$.

The indicators of catalase activity in potato tubers changed similarly.

Treatment of Solánum tuberósum plants with a low concentration of organosilicon growth regulator Energia$\mathrm{M}, 10 \mathrm{mg} / \mathrm{l}$ slightly reduces the activity of peroxidase in potato leaves and amounts to 136 p.u./(g.wet weight*min) (Table 4). Treatment with the growth regulator in a concentration of $50 \mathrm{mg} / 1$ did not differ significantly from the control variant and was equal to 232 p.u./(g. wet weight*min).

Table 4. Effect of the growth regulator Energia-M on the activity of peroxidase in the organs of potato plants

\begin{tabular}{|c|c|c|}
\hline \multirow{2}{*}{ Variant } & \multicolumn{2}{|c|}{$\begin{array}{c}\text { Peroxidase activity, } \\
\text { p.u./(g of wet weight*min) }\end{array}$} \\
\cline { 2 - 3 } & Leaf & tuber \\
\hline Control & $224+11$ & $150 \pm 7$ \\
\hline $\begin{array}{c}\text { Energia }-\mathrm{M}, \\
10 \mathrm{mg} / 1\end{array}$ & $136+7$ & $160 \pm 8$ \\
\hline $\begin{array}{c}\text { Energia - M, } 50 \\
\mathrm{mg} / 1\end{array}$ & $232+12$ & $210 \pm 11$ \\
\hline Energia-M, 80mg/l & $272+14$ & $290 \pm 15$ \\
\hline
\end{tabular}

The treatment of plants with a high concentration of organosilicon growth regulator Energia-M, $80 \mathrm{mg} / 1: 272$ p.u. /(g. wet weight*min) had a greater effect. The increase was 1.21 times.

In Solánum tuberósum tubers of the Zhukovsky cultivar, the peroxidase activity changed similarly to the activity indicators in the leaves.

\section{Conclusion}

The obtained results show that the growth regulator Energia-M in different concentrations influenced the 
development of potato plants grown on the grey forest soils of the Orel region.

The growth regulator Energia-M in a concentration of $80 \mathrm{mg} / \mathrm{l}$ significantly influenced the linear size of shoots and the activity of antioxidant enzymes, in contrast to the concentrations of $10 \mathrm{mg} / \mathrm{l}$. In a concentration of $50 \mathrm{mg} / \mathrm{l}$, the linear dimensions of the shoots were smaller than those of the control plants and proved the absence of a significant effect on the development of potato plants.

The growth activity of Solánum tuberósum (variant Energia -Mt, $80 \mathrm{mg} / \mathrm{l}$ ) was higher than in other studied variants of applying the growth regulator and in the control plants.

An increase in the activity of catalase and peroxidase is associated with the accumulation of peroxides in plant cells with an increase in the intensity of respiration and activation of metabolic processes. This pattern indicates the stimulation of metabolic processes in Solánum tuberósum plants grown on the grey forest soils of the Orel region with the application of the growth regulator Energia-M in a concentration of $80 \mathrm{mg} / \mathrm{l}$.

\section{References}

1. Bezruchko E. V., Zemledelie Silicon as an underestimated plant nutrient 4 40-46 (2020)

2. Slastya I. V. Agricult. Biol. The use of silicon compounds as a factor of raising spring barley cultivars productivity under water stress 482109 119 (2013)

3. Nawaz F., Shabbir R.N., Shahbaz M., Majeed S., Raheel M., Hassan W., Sohail M.A. Phytohormones - signaling mechanisms and crosstalk in plant develop. and stress responses. Cross talk between nitric oxide and phytohormones regulate plant development during abiotic stresses Intech. Chapter 6 117-141 (2017)

4. Lozhnikova V. N., Slastya I. V. Agricul. Biol. Growth of spring barley and activity of endogenous phytohormones activity under the influence of silicon compounds 453 102-107 (2010)

5. Sawicka B. Biostimulators in modern agriculture Rate of spread of fungal diseases on potato plants as affected by application of a bioregulator and foliar fertiliser. Biostimulators in modern agriculture Solanacous crops 68-76 (2008)

6. Zhong Lei, Wang Liangjun, Yuan Jichao, Zheng Shunlin, Hu Jianjun Plant Am. J of Agricult. and Forestry Growth Regulators Affect Germination and Main Carbon-Nitrogen Metabolites of Potato Tubers 7(1) 10-16 (2019)

7. Kozlov A.V., Kulikova A. Kh., Uromova I. P. Agricult. Biol Mobility of silicon, fertility of sodpodzolic soil, bioaccumulation of silicon and yields of agricultural crops under the influence of zeolite 56 1 183-198 (2021)

8. Hu Y.Q., Zhan S., Ku W.Z., et al. Molecular Plant Breeding The Roles of $A B A$ and GA3 in the Joint
Regulation of Potato Tuber Formation and Starch Accumulation in Vitro 1510 4210-4214. (In Chinese with English abstract) (2017)

9. Loginov Yu. P., Kazak A. A. Bull. of the KSAU 1-4 Ecological flexibility of potato cultivars in Tyumen region (61) 24-28 (2015)

10. Dyshko V. N., Dyshko V. V., Romanenko P. V., Sluchenkova N. V. Methods of agrochemical research of soils and plants: an educational and practical manual-Smolensk (SSAA, 2014)

11. Kartashova E. R., Rudenskaya G. P., Yurina E. V. Agricult. Biol Polyfunctionality of plant peroxidases and their practical use 5 63-70 (2000)

12. Konoshina S., Prudnikova E., Mikhaylova Y., Koneeva O., Gorkov A. E3S Web of Conf. Ser. "Int. Sci. and Pract. Conf. "Fund. and Appl. Res. in Biol. and Agricult.: Curr. Iss., Ach. and Inn.", FARBA 2021 The influence of hydroxyaryls of various genesis on the growth and development of winter wheat (Triticum aestivum L.) (2021) 